\title{
Viruses and atypical bacteria in the respiratory tract of immunocompromised and immunocompetent patients with airway infection
}

\author{
Maria Reckziegel ${ }^{1,2} \cdot$ Claudia Weber-Osel $^{1,3} \cdot$ Renate Egerer $^{4} \cdot$ Bernd Gruhn $^{5} \cdot$ Florian Kubek $^{1} \cdot$ Mario Walther $^{6}$. \\ Stefanie Wilhelm ${ }^{1} \cdot$ Roland Zell $^{1} \cdot$ Andi Krumbholz $^{7}$
}

Received: 27 January 2020 / Accepted: 24 March 2020 / Published online: 27 May 2020

(C) The Author(s) 2020, corrected publication 2021

\begin{abstract}
Respiratory tract infections (RTI) can take a serious course under immunosuppression. Data on the impact of the underlying pathogens are still controversial. Samples from the upper $(n=322)$ and lower RT $(n=169)$ were collected from 136 children and 355 adults; 225 among them have been immunocompromised patients. Exclusion criteria were presence of relevant cultivable microorganisms, C-reactive protein $>20 \mathrm{mg} / \mathrm{dl}$, or procalcitonin $>2.0 \mathrm{ng} / \mathrm{ml}$. Samples were tested by PCR for the presence of herpesviruses (HSV-1/-2; VZV; CMV; HHV6; EBV), adenoviruses, bocaviruses, entero-/rhinoviruses (HRV), parechoviruses, coronaviruses, influenza viruses (IV), parainfluenza viruses as well as for pneumoviruses (HMPV and RSV), and atypical bacteria (Mycoplasma pneumoniae, M.p.; Chlamydia pneumoniae, C.p.). Viral/bacterial genome equivalents were detected in more than two-thirds of specimens. Under immunosuppression, herpesviruses (EBV 30.9\%/14.6\%, $p<0.001$; CMV 19.6\%/ $7.9 \%, p<0.001$; HSV-1: $14.2 \% / 7.1 \%, p=0.012$ ) were frequently observed, mainly through their reactivation in adults. Immunocompromised adults tended to present a higher RSV prevalence $(6.4 \% / 2.4 \%, p=0.078)$. Immunocompetent patients were more frequently tested positive for IV $(15.0 \% / 5.8 \%, p=0.001)$ and M.p. $(6.4 \% / 0.4 \%, p<0.001)$, probably biased due to the influenza pandemic of 2009 and an M.p. epidemic in 2011. About $41.8 \%$ of samples were positive for a single pathogen, and among them EBV (19.9\%) was most prevalent followed by HRV (18.2\%) and IV (16.6\%). HSV-2 and C.p. were not found. Marked seasonal effects were observed for HRV, IV, and RSV. Differences in pathogen prevalence were demonstrated between immunocompetent and immunocompromised patients. The exact contribution of some herpesviruses to the development of RTI remains unclear.
\end{abstract}

Keywords Respiratory infection $\cdot$ Immunosuppression $\cdot$ Multiplex PCR $\cdot$ Pathogen spectrum

Maria Reckziegel, Claudia Weber-Osel, Roland Zell and Andi Krumbholz contributed equally to this work.

Electronic supplementary material The online version of this article (https://doi.org/10.1007/s10096-020-03878-9) contains supplementary material, which is available to authorized users.

Andi Krumbholz

krumbholz@infmed.uni-kiel.de

1 Section of Experimental Virology, Institute of Medical Microbiology, Jena University Hospital, Jena, Germany

2 Present address: Department of Hematology/Oncology, Clinic of Internal Medicine II, Jena University Hospital, Jena, Germany

3 Present address: Department of Medicine II, Catholic Hospital 'St. Johann Nepomuk', Erfurt, Germany
4 Institute of Medical Microbiology, Jena University Hospital, Jena, Germany

5 Department of Pediatrics, Jena University Hospital, Jena, Germany

6 Department of Fundamental Sciences, Jena University of Applied Sciences, Jena, Germany

7 Institute of Infection Medicine, Christian-Albrechts-Universität zu Kiel and University Medical Center Schleswig-Holstein, Brunswiker Straße 4, D-24105 Kiel, Germany 


\section{Introduction}

Infections of the upper respiratory tract (URTI) are among the most frequent infections worldwide. These are mainly caused by RNA viruses. Among them, influenza viruses (IV), pneumoviruses (respiratory syncytial virus, RSV; human metapneumovirus, HMPV), but also parainfluenza viruses (PIV), coronaviruses (CoV), and rhinoviruses (HRV) are considered by World Health Organization a global health burden [1]. Serious RTI through respiratory viruses are frequently observed under immunosuppression, for example, in solid organ transplant recipients [2].

The current breakthroughs of immunomodulating therapies in medicine contribute to the continuous increase of patients being under iatrogenic immunosuppression and being at risk for pulmonary infections [3]. In general, suppression of $\mathrm{T}$ cell function is associated with a higher susceptibility for infection or reactivation of various viruses $[4,5]$. Impairment of Th1cell activity but also of humoral immunity, both, facilitates the development of viral RTI. In immunocompromised patients, higher morbidity and sometimes also mortality rates through infections, for example, with adenoviruses (AdV), IV, PIV, RSV, HMPV, but also of secondary complications like bacterial pneumonia have been observed [5-17]. Furthermore, particularly transplant patients are at risk for reactivation of diverse herpesviruses (herpes simplex virus-1/-2, HSV-1/-2; varicella zoster virus, $\mathrm{VZV}$; cytomegalovirus, $\mathrm{CMV}$; human herpesvirus 6, HHV-6; Epstein-Barr virus, EBV) [12, 15, 17-20]. Multiple viral infections/reactivations can occur [21] as well as indirect interactions of viruses with bacteria [22-24]. These aspects may challenge interpretation of diagnostic findings. The frequency of viral infections/reactivations is also influenced by factors like the underlying disease, therapeutic regimes, as well as the type of transplant and HLA mismatches $[12,19]$.

Thus, fast and efficient diagnostic methods that cover a broad spectrum of viruses, bacteria, but also fungi and parasites are in urgent need to deal with the aforementioned challenges. The availability of such methods is of particular importance in stem cell transplant recipients where clinical symptoms of RTI are variable or may be mimicked by graft-versus-host disease [25, 26]. Early diagnosis enables limited antiviral interventions $[16,27]$ and may prevent further cross-transmission [28]. However, detection of viral genome equivalents does not necessarily mean a causative role of this virus, and particularly immunocompromised patients can shed viruses over a prolonged time period $[13,29,30]$. Furthermore, there is increasing evidence of the existence of a respiratory virome which is defined by the presence of common viral pathogens, rare viruses, and viruses of unknown pathogenicity [31]. Thus, the exact contribution of a single virus to the development of RTI is still controversial.
We tried to consider most of these aspects by performing an observational study addressing the spectrum and impact of respiratory viruses but also of herpesviruses and the atypical bacteria Mycoplasma pneumoniae (M.p.) and Chlamydia pneumoniae (C.p.) in patients with respiratory symptoms. For this, an underlying infection through relevant cultivable microorganisms was largely ruled out. Data were analyzed with respect to patients' immune status and age.

\section{Material and methods}

This study included 322 samples from the upper (nasal or throat swabs and washings), and 169 samples from the lower (broncheoalveolar/tracheal washings, induced sputum) respiratory tract (URT/LRT) collected over a period of 40 months beginning in September 2009 to December 2012 from 266 healthy and 225 immunocompromised patients with symptoms of a RTI (i.e., common cold, cough with/without sputum, dyspnea, and fever). This setting included samples from patients with respiratory symptoms under neutropenia or lungtransplant recipients with a recently observed decrease in forced expiratory volume in one second (FEV1). A compromised immune status was defined (i) for solid organ or stem cell transplant recipients under iatrogenic immunosuppression, (ii) in patients with autoimmune disorders under immunosuppressing therapy but also (iii) in cancer patients under chemotherapy/radiation, and (iv) in patients with primary or secondary causes of immunodeficiency including HIV infection.

Samples found to contain relevant cultivable bacteria (Streptococcus pneumoniae, Staphylococcus aureus, Haemophilus influenzae, various Enterobacterales and nonfermenting Gram-negative bacteria, Mycobacterium tuberculosis) and fungi were excluded. Furthermore, specimens obtained from patients with a present bacteremia/ sepsis were excluded as well as samples from patients with RTI through Pneumocystis jirovecii or Legionella pneumophila. The oropharyngeal and tracheopulmonal flora was considered if data were available from routine diagnostics. In addition, samples obtained from the LRT of patients with more than 100,000 colonies/ml of oropharyngeal or tracheopulmonal flora, or more than 10,000 colonies $/ \mathrm{ml}$ of Enterococcus spp. or Candida spp., were also excluded since such high concentrations may represent an infection rather than colonization. In addition, the presence of procalcitonin (PCT) $>2 \mathrm{ng} / \mathrm{ml}$ and/or of C-reactive protein $(\mathrm{CRP})>20 \mathrm{mg} /$ $\mathrm{dl}$ in serum leads to exclusion of the RT sample.

The remaining samples were obtained from $99 \mathrm{immu}-$ nocompetent (median age 1.0 years; 56 males/43 females) and 37 immunocompromised (median age 4.6 years; 18 males/19 females) children and adolescents as well as 167 
immunocompetent (median age 46.2 years; 73 males/94 females) and 188 (median age: 57.2 years; 101 males/87 females) immunocompromised adults. Among the immunocompromised cohort, most samples were obtained from patients with hemato-oncological malignancies $(28.4 \%)$, followed by samples from patients after organ $(24.9 \%)$ and stem cell $(16.4 \%)$ transplantation or with autoimmune disorders (13.8\%). About $9.8 \%$ of samples were included from patients with other conditions of immunosuppression or from solid tumor patients $(6.7 \%)$.

Specimens were immediately deep frozen $\left(-80^{\circ} \mathrm{C}\right)$ until nucleic acid extraction. The extraction was done manually with the QIAamp MinElute Virus Spin Kit or automatically with the EZ1 Virus Mini Kit (both QIAGEN, Hilden, Germany). The nucleic acids were stored at $-20{ }^{\circ} \mathrm{C}$ and used for synthesis of copy DNA (cDNA) applying the RevertAid H Minus First Strand cDNA Synthesis Kit (ThermoFisher Scientific, Langen, Germany) with random hexamers. Integrity of cDNA was demonstrated by amplification of $\beta$-actin or glyceraldehyde 3-phosphate dehydrogenase (GAPDH) DNA [32, 33] with DreamTaq DNA Polymerase (ThermoFisher Scientific). Presence of herpesviral DNA (HSV-1/-2, VZV, CMV, and HHV-6) was demonstrated by applying conventional PCR [34-41] together with the HotStarTaq DNA polymerase and Qsolution (QIAGEN). Quantitative detection of EBV DNA in samples from the LRT was done in accordance with Krumbholz et al. (2006) [42], but SYBR-green (QuantiTect SYBR Green PCR Kit; QIAGEN) was used instead of hybridization probes. These diagnostic PCRs were continuously approved by successful participation in the External Quality Assurance Service (EQAS) program of Instand e.V. (Düsseldorf, Germany).

For detection of diverse respiratory viruses, all cDNAs were tested with the Seeplex RV5 ACE (covers IV-A; IV-B; RSV-A/-B; AdV; PIV1-3; bocavirus, BoV; HMPV; HRV-A/ B; CoV 229E/NL63/OC43/HKU1) and RV12 (covers the same spectrum as RV5, but is not able to detect BoV) ACE Detection Kits. The Seeplex RV15 ACE Detection Kit (includes also PIV-4, HRV-C, and enterovirus detection but is not able to detect CoV HKU1) was used from November 2011, since the distribution of RV5 and RV12 versions was abandoned (all Kits Seegene, Eschborn, Germany). All three multiplex assays have been established in the laboratory using defined EQAS samples from Instand e.V. before testing of study samples. The RV5 Kit is a screening kit and neither allows discrimination between AdV, PIV, and BoV nor between HMPV, HRV, and CoV. To overcome this problem, amplicons were purified after agarose gel-electrophoresis applying the QIAquick Gel Extraction Kit (QIAGEN). Purified DNA was ligated into the pDRIVE cloning vector included in the QIAGEN PCR Cloning Kit, and used for transformation of competent Escherichia coli cells. Then, colonies were screened for inserts by PCR applying the DreamTaq DNA Polymerase and oligonucleotides specific for pDRIVE. Amplicons with inserts were purified and sequenced using the DTCS Quick Start Master Mix. Sequence analysis was done on a Beckman CEQ 8000 Genetic Analyzer (all Beckman Coulter, Krefeld, Germany).

For detection of human parechovirus (HPeV) genome equivalents, a semiquantitative real-time PCR was established using cDNA and oligonucleotides [43] together with the QuantiTect SYBR Green PCR Kit (QIAGEN) on a LightCycler 1.5 (Roche, Mannheim, Germany). Positive controls for HPeV-PCR were kindly provided by Dr. Corinna Pietsch and Prof. Dr. Uwe Gerd Liebert (Institute of Virology, University of Leipzig, Germany).

Since enteroviruses were not covered by RV5 and RV12 assays, nearly all samples were screened by a nested PCR protocol detecting a conserved sequence of the $5^{\prime}$ nontranslated region (5'-NTR) [44]. Then, rough-typing was done by sequence analysis of purified PCR products. Detection of HRV was performed by nested amplification of the VP4/2-encoding region [45].

Parallel testing for M.p. and C.p. was done by applying the Diagenode Mycoplasma pneumoniae and Chlamydophila pneumoniae Kit (R-DiaMCpn, Diagenode s. a., Liège, Belgium) on an ABI7500 real-time PCR system (ThermoFisher Scientific).

Sequence data were analyzed using MEGA 6.0 [46]. All other data were analyzed applying the two-sided Fisher's exact test implemented in IBM® SPSS $®$ Statistics 20. A $p$ value $<0.05$ was considered statistically significant.

\section{Results}

This study included 491 samples from immunocompromised or immunocompetent patients with symptoms of RTI collected over a period of 40 months. All samples tested positive for the presence of GAPDH and/or B-actin. Thus, quality of sampling and nucleic acid extraction was demonstrated (data not shown).

Among the overall study population, genome equivalents of EBV were most frequently detected $(22.3 \%, 84 / 377)$, followed by HHV-6 (20.3\%, 32/158), HRV (14.1\%, 69/ 491), CMV (13.2\%, 65/491), RSV (11.2\%, 55/491), and IV (10.8\%, 53/491). Genome equivalents of HSV-2 and C.p. were generally not detected (Table 1).

With respect to patients' immune status, DNA of EBV (30.9\% vs. $14.6 \%)$, CMV (19.6\% vs. $7.9 \%)$, and HSV-1 (14.2\% vs. $7.1 \%$ ) was significantly more prevalent in immunocompromised patients while genome equivalents of IV $(5.8 \%$ vs. $15.0 \%)$ or M.p. $(0.4 \%$ vs. $6.4 \%)$ were more frequently observed in their immunocompetent counterpart. The higher prevalence of CMV and EBV was only observed 
Table 1 Prevalence of respiratory viruses, herpesviruses, and atypical bacteria C.p. and M.p. in the upper and lower respiratory tract (URT/LRT) of immunocompromised and immunocompetent patients. The pathogens are listed in alphabetical order

\begin{tabular}{|c|c|c|c|c|c|c|}
\hline & \multicolumn{3}{|c|}{ Immunocompromised patients } & \multicolumn{3}{|c|}{ Immunocompetent patients } \\
\hline & Total & URT & LRT & Total & URT & LRT \\
\hline \multicolumn{7}{|c|}{ (a) Overall study population } \\
\hline \multicolumn{7}{|c|}{ Respiratory viruses } \\
\hline $\mathrm{AdV}$ & $3 / 225(1.3 \%)$ & $1 / 110(0.9 \%)$ & $2 / 115(1.7 \%)$ & $5 / 266(1.9 \%)$ & $4 / 212(1.9 \%)$ & $1 / 54(1.9 \%)$ \\
\hline $\mathrm{BoV}$ & $4 / 225(1.8 \%)$ & $3 / 110(2.7 \%)$ & $1 / 115(0.9 \%)$ & $8 / 266(3.0 \%)$ & $8 / 212(3.8 \%)$ & $0 / 54(0.0 \%)$ \\
\hline $\mathrm{CoV}$ & $6 / 225(2.7 \%)$ & $4 / 110(3.6 \%)$ & $2 / 115(1.7 \%)$ & $9 / 266(3.4 \%)$ & $8 / 212(3.8 \%)$ & $1 / 54(1.9 \%)$ \\
\hline EV & $2 / 222(0.9 \%)$ & $1 / 109(0.9 \%)$ & $1 / 113(0.9 \%)$ & $8 / 264(3.0 \%)$ & $8 / 210(3.8 \%)$ & $0 / 54(0.0 \%)$ \\
\hline HMPV & $4 / 225(1.8 \%)$ & $3 / 110(2.7 \%)$ & $1 / 115(0.9 \%)$ & $7 / 266(2.6 \%)$ & $7 / 212(3.3 \%)$ & $0 / 54(0.0 \%)$ \\
\hline $\mathrm{HPeV}$ & $0 / 222(0.0 \%)$ & $0 / 109(0.0 \%)$ & $0 / 113(0.0 \%)$ & $1 / 264(0.4 \%)$ & $1 / 210(0.5 \%)$ & $0 / 54(0.0 \%)$ \\
\hline HRV & $30 / 225(13.3 \%)$ & $15 / 110(13.6 \%)$ & $15 / 115(13.0 \%)$ & $39 / 266(14.7 \%)$ & $35 / 212(16.5 \%)$ & $4 / 54(7.4 \%)$ \\
\hline IV & $13 / 225(5.8 \%)^{\mathrm{d}}$ & $11 / 110(10.0 \%)^{\mathrm{a}}$ & $2 / 115(1.7 \%)$ & $40 / 266(15.0 \%)^{\mathrm{d}}$ & $40 / 212(18.9 \%)^{\mathrm{a}}$ & $0 / 54(0.0 \%)$ \\
\hline PIV & $7 / 225(3.1 \%)$ & $4 / 110(3.6 \%)$ & $3 / 115(2.6 \%)$ & $5 / 266(1.9 \%)$ & $5 / 212(2.4 \%)$ & $0 / 54(0.0 \%)$ \\
\hline RSV & $20 / 225(8.9 \%)$ & $14 / 110(12.7 \%)$ & $6 / 115(5.2 \%)$ & $35 / 266(13.2 \%)$ & $31 / 212(14.6 \%)$ & $4 / 54(7.4 \%)$ \\
\hline \multicolumn{7}{|c|}{ Herpesviruses } \\
\hline CMV & $44 / 225(19.6 \%)^{\mathrm{d}}$ & $13 / 110(11.8 \%)$ & $31 / 115(27.0 \%)^{\mathrm{b}}$ & $21 / 266(7.9 \%)^{\mathrm{d}}$ & $15 / 212(7.1 \%)$ & $6 / 54(11.1 \%)^{\mathrm{b}}$ \\
\hline EBV & $55 / 178(30.9 \%)^{\mathrm{d}}$ & $18 / 65(27.7 \%)^{\mathrm{c}}$ & $37 / 113(32.7 \%)$ & $29 / 199(14.6 \%)^{\mathrm{d}}$ & $17 / 147(11.6 \%)^{\mathrm{c}}$ & $12 / 52(23.1 \%)$ \\
\hline HHV-6 & $15 / 71(21.1 \%)$ & $6 / 23(26.1 \%)$ & $9 / 48(18.8 \%)$ & $17 / 87(19.5 \%)$ & $10 / 58(17.2 \%)$ & $7 / 29(24.1 \%)$ \\
\hline HSV-1 & $32 / 225(14.2 \%)^{\mathrm{b}}$ & $16 / 110(14.5 \%)^{\mathrm{b}}$ & $16 / 115(13.9 \%)$ & $19 / 266(7.1 \%)^{\mathrm{b}}$ & $14 / 212(6.6 \%)^{b}$ & $5 / 54(9.3 \%)$ \\
\hline HSV-2 & $0 / 225(0.0 \%)$ & $0 / 110(0.0 \%)$ & $0 / 115(0.0 \%)$ & $0 / 266(0.0 \%)$ & $0 / 212(0.0 \%)$ & $0 / 54(0.0 \%)$ \\
\hline VZV & $0 / 83(0.0 \%)$ & $0 / 42(0.0 \%)$ & $0 / 41(0.0 \%)$ & $1 / 107(0.9 \%)$ & $1 / 88(1.1 \%)$ & $0 / 19(0.0 \%)$ \\
\hline \multicolumn{7}{|c|}{ Atypical bacteria } \\
\hline C.p. & $0 / 225(0.0 \%)$ & $0 / 110(0.0 \%)$ & $0 / 115(0.0 \%)$ & $0 / 266(0.0 \%)$ & $0 / 212(0.0 \%)$ & $0 / 54(0.0 \%)$ \\
\hline M.p. & $1 / 225(0.4 \%)^{\mathrm{d}}$ & $0 / 110(0.0 \%)^{\mathrm{b}}$ & $1 / 115(0.9 \%)^{\mathrm{c}}$ & $17 / 266(6.4 \%)^{\mathrm{d}}$ & $11 / 212(5.2 \%)^{\mathrm{b}}$ & $6 / 54(11.1 \%)^{\mathrm{c}}$ \\
\hline \multicolumn{7}{|c|}{ None of these pathogens } \\
\hline & $75 / 225(33.3 \%)$ & - & - & $82 / 266(30.8 \%)$ & - & - \\
\hline \multicolumn{7}{|l|}{ (b) Children } \\
\hline \multicolumn{7}{|c|}{ Respiratory viruses } \\
\hline $\mathrm{AdV}$ & $0 / 37(0.0 \%)$ & $0 / 35(0.0 \%)$ & $0 / 2(0.0 \%)$ & $4 / 99(4.0 \%)$ & $3 / 95(3.2 \%)$ & $1 / 4(25.0 \%)$ \\
\hline $\mathrm{BoV}$ & $2 / 37(5.4 \%)$ & $2 / 35(5.7 \%)$ & $0 / 2(0.0 \%)$ & $7 / 99(7.1 \%)$ & $7 / 95(7.4 \%)$ & $0 / 4(0.0 \%)$ \\
\hline $\mathrm{CoV}$ & $2 / 37(5.4 \%)$ & $1 / 35(2.9 \%)$ & $1 / 2(50.0 \%)$ & $6 / 99(6.1 \%)$ & $6 / 95(6.3 \%)$ & $0 / 4(0.0 \%)$ \\
\hline $\mathrm{EV}$ & $0 / 37(0.0 \%)$ & $0 / 35(0.0 \%)$ & $0 / 2(0.0 \%)$ & $6 / 98(6.1 \%)$ & $6 / 94(6.4 \%)$ & $0 / 4(0.0 \%)$ \\
\hline HMPV & $2 / 37(5.4 \%)$ & $2 / 35(5.7 \%)$ & $0 / 2(0.0 \%)$ & $4 / 99(4.0 \%)$ & $4 / 95(4.2 \%)$ & $0 / 4(0.0 \%)$ \\
\hline $\mathrm{HPeV}$ & $0 / 37(0.0 \%)$ & $0 / 35(0.0 \%)$ & $0 / 2(0.0 \%)$ & $1 / 98(1.0 \%)$ & $1 / 94(1.1 \%)$ & $0 / 4(0.0 \%)$ \\
\hline HRV & $9 / 37(24.3 \%)$ & $9 / 35(25.7 \%)$ & $0 / 2(0.0 \%)$ & $26 / 99(26.3 \%)$ & $25 / 95(26.3 \%)$ & $1 / 4(25.0 \%)$ \\
\hline IV & $2 / 37(5.4 \%)$ & $2 / 35(5.7 \%)$ & $0 / 2(0.0 \%)$ & $12 / 99(12.1 \%)$ & $12 / 95(12.6 \%)$ & $0 / 4(0.0 \%)$ \\
\hline PIV & $1 / 37(2.7 \%)$ & $1 / 35(2.9 \%)$ & $0 / 2(0.0 \%)$ & $2 / 99(2.0 \%)$ & $2 / 95(2.1 \%)$ & $0 / 4(0.0 \%)$ \\
\hline RSV & $8 / 37(21.6 \%)$ & $8 / 35(22.9 \%)$ & $0 / 2(0.0 \%)$ & $31 / 99(31.3 \%)$ & $29 / 95(30.5 \%)$ & $2 / 4(50.0 \%)$ \\
\hline \multicolumn{7}{|c|}{ Herpesviruses } \\
\hline $\mathrm{CMV}$ & $0 / 37(0.0 \%)^{\mathrm{b}}$ & $0 / 35(0.0 \%)^{\mathrm{b}}$ & $0 / 2(0.0 \%)$ & $11 / 99(11.1 \%)^{\mathrm{b}}$ & $11 / 95(11.6 \%)^{\mathrm{b}}$ & $0 / 4(0.0 \%)$ \\
\hline EBV & $0 / 16(0.0 \%)$ & $0 / 14(0.0 \%)$ & $0 / 2(0.0 \%)$ & $2 / 73(2.7 \%)$ & $2 / 70(2.9 \%)$ & $0 / 3(0.0 \%)$ \\
\hline HHV-6 & $0 / 5(0.0 \%)$ & $0 / 3(0.0 \%)$ & $0 / 2(0.0 \%)$ & $6 / 35(17.1 \%)$ & $6 / 33(18.2 \%)$ & $0 / 2(0.0 \%)$ \\
\hline HSV-1 & $1 / 37(2.7 \%)$ & $1 / 35(2.9 \%)$ & $0 / 2(0.0 \%)$ & $2 / 99(2.0 \%)$ & $2 / 95(2.1 \%)$ & $0 / 4(0.0 \%)$ \\
\hline HSV-2 & $0 / 37(0.0 \%)$ & $0 / 35(0.0 \%)$ & $0 / 2(0.0 \%)$ & $0 / 99(0.0 \%)$ & $0 / 95(0.0 \%)$ & $0 / 4(0.0 \%)$ \\
\hline VZV & $0 / 11(0.0 \%)$ & $0 / 11(0.0 \%)$ & - & $0 / 37(0.0 \%)$ & $0 / 37(0.0 \%)$ & - \\
\hline \multicolumn{7}{|c|}{ Atypical bacteria } \\
\hline C.p. & $0 / 37(0.0 \%)$ & $0 / 35(0.0 \%)$ & $0 / 2(0.0 \%)$ & $0 / 99(0.0 \%)$ & $0 / 95(0.0 \%)$ & $0 / 4(0.0 \%)$ \\
\hline M.p. & $0 / 37(0.0 \%)$ & $0 / 35(0.0 \%)$ & $0 / 2(0.0 \%)$ & $1 / 99(1.0 \%)$ & $1 / 95(1.1 \%)$ & $0 / 4(0.0 \%)$ \\
\hline
\end{tabular}


Table 1 (continued)

\begin{tabular}{|c|c|c|c|c|c|c|}
\hline & \multicolumn{3}{|c|}{ Immunocompromised patients } & \multicolumn{3}{|c|}{ Immunocompetent patients } \\
\hline & Total & URT & LRT & Total & URT & LRT \\
\hline \multicolumn{7}{|c|}{ None of these pathogens } \\
\hline & $17 / 37(45.9 \%)^{\mathrm{d}}$ & - & - & $18 / 99(18.2 \%)^{\mathrm{d}}$ & - & - \\
\hline \multicolumn{7}{|l|}{ (c) Adults } \\
\hline \multicolumn{7}{|c|}{ Respiratory viruses } \\
\hline $\mathrm{AdV}$ & $3 / 188(1.6 \%)$ & $1 / 75(1.3 \%)$ & $2 / 113(1.8 \%)$ & $1 / 167(0.6 \%)$ & $1 / 117(0.9 \%)$ & $0 / 50(0.0 \%)$ \\
\hline $\mathrm{BoV}$ & $2 / 188(1.1 \%)$ & $1 / 75(1.3 \%)$ & $1 / 113(0.9 \%)$ & $1 / 167(0.6 \%)$ & $1 / 117(0.9 \%)$ & $0 / 50(0.0 \%)$ \\
\hline $\mathrm{CoV}$ & $4 / 188(2.1 \%)$ & $3 / 75(4.0 \%)$ & $1 / 113(0.9 \%)$ & $3 / 167(1.8 \%)$ & $2 / 117(1.7 \%)$ & $1 / 50(2.0 \%)$ \\
\hline $\mathrm{EV}$ & $2 / 185(1.1 \%)$ & $1 / 74(1.4 \%)$ & $1 / 111(0.9 \%)$ & $2 / 166(1.2 \%)$ & $2 / 116(1.7 \%)$ & $0 / 50(0.0 \%)$ \\
\hline HMPV & $2 / 188(1.1 \%)$ & $1 / 75(1.3 \%)$ & $1 / 113(0.9 \%)$ & $3 / 167(1.8 \%)$ & $3 / 117(2.6 \%)$ & $0 / 50(0.0 \%)$ \\
\hline $\mathrm{HPeV}$ & $0 / 185(0.0 \%)$ & $0 / 74(0.0 \%)$ & $0 / 111(0.0 \%)$ & $0 / 166(0.0 \%)$ & $0 / 116(0.0 \%)$ & $0 / 50(0.0 \%)$ \\
\hline HRV & $21 / 188(11.2 \%)$ & $6 / 75(8.0 \%)$ & $15 / 113(13.3 \%)$ & $13 / 167(7.8 \%)$ & $10 / 117(8.5 \%)$ & $3 / 50(6.0 \%)$ \\
\hline IV & $11 / 188(5.9 \%)^{\mathrm{c}}$ & $9 / 75(12.0 \%)^{\mathrm{a}}$ & $2 / 113(1.8 \%)$ & $28 / 167(16.8 \%)^{\mathrm{c}}$ & $28 / 117(23.9)^{\mathrm{a}}$ & $0 / 50(0.0 \%)$ \\
\hline PIV & $6 / 188(3.2 \%)$ & $3 / 75(4.0 \%)$ & $3 / 113(2.7 \%)$ & $3 / 167(1.8 \%)$ & $3 / 117(2.6 \%)$ & $0 / 50(0.0 \%)$ \\
\hline RSV & $12 / 188(6.4 \%)^{\mathrm{a}}$ & $6 / 75(8.0 \%)^{\mathrm{a}}$ & $6 / 113(5.3 \%)$ & $4 / 167(2.4 \%)^{\mathrm{a}}$ & $2 / 117(1.7 \%)^{\mathrm{a}}$ & $2 / 50(4.0 \%)$ \\
\hline \multicolumn{7}{|c|}{ Herpesviruses } \\
\hline CMV & $44 / 188(23.4 \%)^{\mathrm{d}}$ & $13 / 75(17.3 \%)^{\mathrm{c}}$ & $31 / 113(27.4 \%)^{\mathrm{b}}$ & $10 / 167(6.0 \%)^{\mathrm{d}}$ & $4 / 117(3.4 \%)^{\mathrm{c}}$ & $6 / 50(12.0 \%)^{\mathrm{b}}$ \\
\hline EBV & $55 / 162(34.0 \%)^{\mathrm{b}}$ & $18 / 51(35.3 \%)^{\mathrm{a}}$ & $37 / 111(33.3 \%)$ & $27 / 126(21.4 \%)^{\mathrm{b}}$ & $15 / 77(19.5 \%)^{\mathrm{a}}$ & $12 / 49(24.5 \%)$ \\
\hline HHV-6 & $15 / 66(22.7 \%)$ & $6 / 20(30.0 \%)$ & $9 / 46(19.6 \%)$ & $11 / 52(21.2 \%)$ & $4 / 25(16.0 \%)$ & $7 / 27(25.9 \%)$ \\
\hline HSV-1 & $31 / 188(16.5 \%)^{\mathrm{a}}$ & $15 / 75(20.0 \%)^{\mathrm{a}}$ & $16 / 113(14.2 \%)$ & $17 / 167(10.2 \%)^{\mathrm{a}}$ & $12 / 117(10.3 \%)^{\mathrm{a}}$ & $5 / 50(10.0 \%)$ \\
\hline HSV-2 & $0 / 188(0.0 \%)$ & $0 / 75(0.0 \%)$ & $0 / 113(0.0 \%)$ & $0 / 167(0.0 \%)$ & $0 / 117(0.0 \%)$ & $0 / 50(0.0 \%)$ \\
\hline VZV & $0 / 72(0.0 \%)$ & $0 / 31(0.0 \%)$ & $0 / 41(0.0 \%)$ & $1 / 70(1.4 \%)$ & $1 / 51(2.0 \%)$ & $0 / 19(0.0 \%)$ \\
\hline \multicolumn{7}{|c|}{ Atypical bacteria } \\
\hline C.p. & $0 / 188(0.0 \%)$ & $0 / 75(0.0 \%)$ & $0 / 113(0.0 \%)$ & $0 / 167(0.0 \%)$ & $0 / 117(0.0 \%)$ & $0 / 50(0.0 \%)$ \\
\hline M.p. & $1 / 188(0.5 \%)^{\mathrm{d}}$ & $0 / 75(0.0 \%)^{\mathrm{c}}$ & $1 / 113(0.9 \%)^{\mathrm{c}}$ & $16 / 167(9.6 \%)^{\mathrm{d}}$ & $10 / 117(8.5 \%)^{\mathrm{c}}$ & $6 / 50(12.0 \%)^{\mathrm{c}}$ \\
\hline \multicolumn{7}{|c|}{ None of these pathogens } \\
\hline & $58 / 188(30.6 \%)$ & - & - & $64 / 167(38.3 \%)$ & - & - \\
\hline
\end{tabular}

Four hundred eighty-six of the 491 samples were tested for EV/HPeV, 377 for EBV, 190 for VZV, and 158 for the presence of HHV-6 DNA, respectively

$A d V$ adenovirus, $B o V$ bocavirus, $C M V$ cytomegalovirus, $C o V$ coronavirus, $C . p$. Chlamydia pneumoniae, EBV Epstein-Barr virus, $E V$ enterovirus, $H H V$ 6 human herpesvirus 6, $H M P V$ human metapneumovirus, $H P e V$ human parechovirus, $H R V$ human rhinovirus, $H S V$ - 1 herpes simplex virus 1 , $H S V$-2 herpes simplex virus 2, M.p. Mycoplasma pneumoniae, $P I V$ influenza virus, $P I V$ parainfluenza virus, $R S V$ respiratory syncytial virus, $V Z V$ varicellazoster virus

${ }^{\text {a }}$ Level of significance up to $10 \%$

${ }^{\mathrm{b}}$ Level of significance up to $5 \%$

${ }^{\mathrm{c}}$ Level of significance up to $1 \%$

${ }^{\mathrm{d}}$ Level of significance up to $\leq 0.1 \%$

in immunocompromised adults $(23.4 \%$ vs. $6.0 \%$ and $34.0 \%$ vs. $21.4 \%$, respectively). Moreover, this patient group tended to present a higher prevalence of HSV-1 (16.5\% vs. $10.2 \%)$ and RSV (6.4\% vs. $2.4 \%$ ) (Table 1). The median concentration of EBV DNA in the LRT was significantly higher in immunocompromised patients. Moreover, this group presented a higher prevalence of EBV concentration exceeding 100,000 copies/ml (Fig. 1, Supplementary Table 1). Roughly one-third $(35.7 \%, 30 / 84)$ of all EBV genome detections were not associated with other pathogens, while twothirds of EBV-positive samples revealed double (42.9\%, 36/
$84)$ or multiple $(21.4 \%, 18 / 84)$ detections together with other viruses (Supplementary Fig. 1).

In 26.3\% (129/491) of samples found to be pathogen-positive, multiple agents were detected. Among them were samples with two (20.4\%), three (5.1\%), four $(0.6 \%)$, or even five $(0.2 \%)$ different viruses/bacteria (Supplementary Fig. 1). The combination of two herpesviruses (HHV-6/EBV 13.2\%, 5/38; CMV/EBV 9.6\%, 8/83; CMV/HSV-1 8.0\%, 8/100) but also of EBV and IV $(6.0 \%, 5 / 83)$ or M.p. $(6.0 \%, 5 / 83)$ as well as of RSV and HRV $(5.0 \%, 5 / 100)$ was frequently observed. Bocaviral DNA was found together with other viruses/M.p. 
Fig. 1 Comparison of EBV-DNA copies $/ \mathrm{ml}$ in respiratory specimens from immunocompromised and immunocompetent patients. Data are presented in a logarithmic scale. The median EBV concentration is significantly higher in immunocompromised patients ( $p=0.030$, MannWhitney $U$ test)

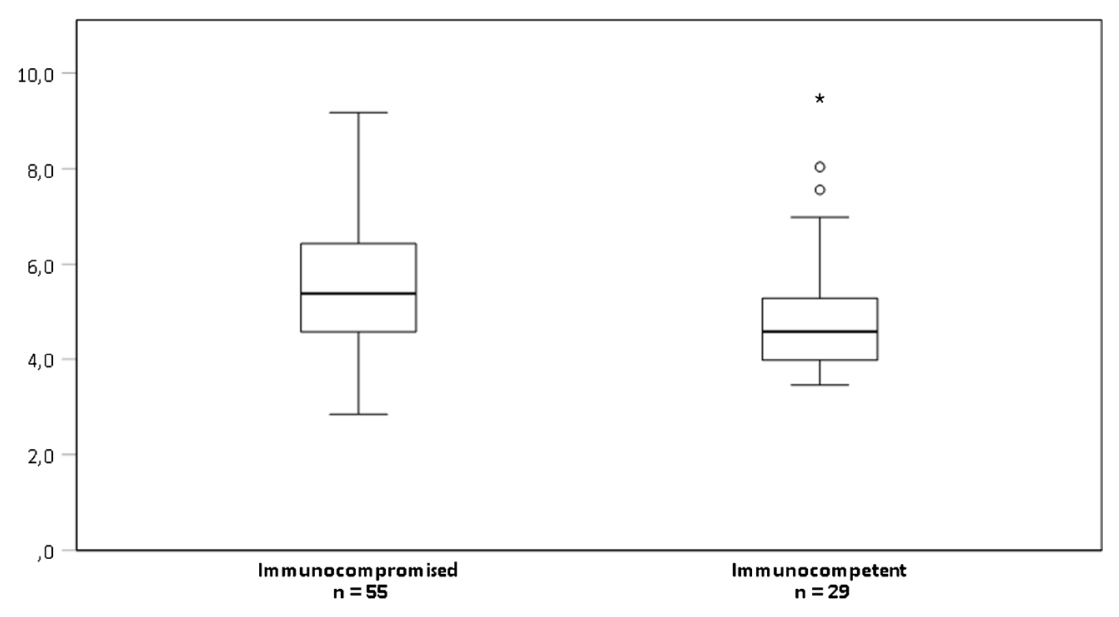

$(74.9 \%, 9 / 12)$. However, in younger children ( $\leq 2$ years), monoinfections through BoV were observed (Table 2, Supplementary Fig. 1).

Significant seasonal effects were recorded in the immunocompetent group for HRV with a high prevalence in autumn and for IV with an increased prevalence in winter. Seasonal effect was significant in both patient groups for RSV with increased prevalence in winter and spring (Supplementary Table 2). Interestingly, slight seasonality was also observed for HHV-6 in the immunocompetent group. In addition, some interannual variation was found for M.p. and IV (data not shown), which was most likely associated to the 2009influenza pandemic and an M.p. epidemic in 2011, respectively.

\section{Discussion}

In this monocentric study, genome equivalents of viruses and M.p. were frequently detected in immunocompromised $(66.7 \%)$ and immunocompetent $(69.2 \%)$ patients with respiratory symptoms (Table 1 ).

Since a contribution of relevant cultivable microorganisms to patient symptoms was largely excluded, a causative role of the pathogens detected in this study has to be considered. Previously, a comparable approach was used to identify viral causes of severe RTI in children [47]. The stringent exclusion criteria may account for the low number of patient samples included in this study and may have neglected possible additive or synergistic effects between bacteria, fungi, and viruses.

In particular, we found a high prevalence of herpesviruses in immunocompromised adults with respiratory infections. Nearly one-third of them was tested positive for EBV and every fourth patient presented CMV in his respiratory tract. In children, herpesviral DNA was rarely detected which reflects the generally increasing infestation rate observed over life-time [48-52] and indicates viral reactivation as a major cause for pathogen detection. The higher prevalence of EBV,
CMV, and HSV-1 in the airways of adults was associated with the state of immunosuppression. This is in line with the fact that herpesviral reactivation is facilitated by the impaired immune system [53]. It is still controversial whether this reactivation contributes to respiratory pathology or just represents an indicator of excessive immunosuppression. For CMV, however, there is no doubt that this betaherpesvirus is responsible for LRTI in immunocompromised patients [17, 20]. CMV pneumonia is considered as likely when viral DNA has been detected in BAL of symptomatic patients [17]. Thus, in our study, a remarkable proportion of immunocompromised adults revealed signs of suspected CMV pneumonia (Table 1) and may benefit from antiviral prophylaxis or therapy.

While HSV-1 DNA was slightly more prevalent in the URT of immunocompromised patients, we found nearly comparable detection rates in the LRT of both patients groups (Table 1). This is in line with a previous study [54]. Interestingly, the same authors found that higher HSV-1 concentrations were associated with a poor patient outcome [54]. As for CMV, definitive diagnosis of HSV-1 pneumonitis depends on the presence of viral antigen within the LRT tissues [17].

In contrast to a recent report [55], we found two-times higher EBV DNA prevalence in immunocompromised patients compared to their immunocompetent counterparts (Table 1). Previously, EBV DNA was frequently detected in patients with pneumonia, respiratory insufficiency, and other bronchopneumopathies, but its presence was not associated with increased 28-day mortality [55]. In addition, the same authors reported no difference in EBV concentration between immunocompromised and immunocompetent patients [55], which is in contrast to our findings (Fig. 1, Supplementary Table 1). Nevertheless, the contribution of EBV to the development of respiratory symptoms is still controversially discussed in the literature and remains unclear so far [55-57]. There is, however, some evidence that EBV reactivation-like that of other herpesviruses - may trigger 
Table 2 Detection of multiple pathogens in the respiratory tract of the overall study population (a) as well as of immunocompromised (b) and immunocompetent (c) patients. The gray boxes indicate frequent co-infections. Note that due to multiple detection (i.e., more than two pathogens), the sum of the frequencies given in these boxes may be higher the total frequency given in the black box. See also Suppl. Figure 1

\begin{tabular}{|c|c|c|c|c|c|c|c|c|c|c|c|c|c|c|c|c|c|c|}
\hline $\begin{array}{l}\text { a) Overall study } \\
\text { population }\end{array}$ & zे & ेे & نे & 齐 & 主 & $\begin{array}{l}\text { dे } \\
\stackrel{\varrho}{I}\end{array}$ & $\underset{⿱ 亠 乂}{\stackrel{x}{\not}}$ & $\stackrel{\mathbb{R}}{\geq}$ & $\stackrel{\infty}{\geq}$ & $\grave{a}$ & 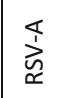 & $\sum_{\tilde{丶}}^{\infty}$ & $\sum_{U}$ & 豈 & 足 & 竞 & $\stackrel{\lambda}{>}$ & $\stackrel{\dot{\alpha}}{\dot{\Sigma}}$ \\
\hline & 491 & 491 & 491 & 486 & 491 & 486 & 491 & 491 & 491 & 491 & 491 & 491 & 491 & 377 & 158 & 491 & 190 & 491 \\
\hline $\mathrm{AdV}$ & 8 & 0 & 0 & 0 & 0 & 0 & 2 & 0 & 0 & 0 & 1 & 1 & 1 & 0 & 1 & 0 & 0 & 0 \\
\hline BoV & & 12 & 2 & 0 & 0 & 0 & 4 & 1 & 0 & 0 & 1 & 3 & 2 & 1 & 1 & 0 & 0 & 0 \\
\hline $\mathrm{CoV}$ & & & 15 & 0 & 0 & 0 & 3 & 1 & 0 & 0 & 2 & 1 & 1 & 1 & 3 & 3 & 0 & 0 \\
\hline EV & & & & 10 & 0 & 0 & 1 & 2 & 0 & 1 & 1 & 1 & 0 & 1 & 0 & 1 & 0 & 0 \\
\hline HMPV & & & & & 11 & 0 & 1 & 0 & 0 & 0 & 0 & 0 & 1 & 0 & 0 & 1 & 0 & 0 \\
\hline HPeV & & & & & & 1 & 0 & 1 & 0 & 0 & 0 & 0 & 0 & 0 & 0 & 0 & 0 & 0 \\
\hline HRV & & & & & & & 69 & 2 & 0 & 2 & 5 & 1 & 6 & 9 & 3 & 1 & 0 & 2 \\
\hline IV-A & & & & & & & & 49 & 0 & 0 & 1 & 1 & 4 & 5 & 4 & 3 & 0 & 0 \\
\hline IV-B & & & & & & & & & 4 & 0 & 0 & 0 & 0 & 2 & 0 & 0 & 0 & 0 \\
\hline PIV & & & & & & & & & & 12 & 1 & 0 & 1 & 3 & 1 & 1 & 0 & 0 \\
\hline RSV-A & & & & & & & & & & & 38 & 0 & 6 & 4 & 1 & 2 & 0 & 0 \\
\hline RSV-B & & & & & & & & & & & & 17 & 3 & 2 & 2 & 0 & 0 & 0 \\
\hline $\mathrm{CMV}$ & & & & & & & & & & & & & 65 & 19 & 7 & 13 & 0 & 1 \\
\hline EBV & & & & & & & & & & & & & & 84 & 10 & 10 & 0 & 8 \\
\hline HHV-6 & & & & & & & & & & & & & & & 32 & 5 & - & 2 \\
\hline HSV-1 & & & & & & & & & & & & & & & & 51 & 0 & 2 \\
\hline VZV & & & & & & & & & & & & & & & & & 1 & 0 \\
\hline M.p. & & & & & & & & & & & & & & & & & & 18 \\
\hline
\end{tabular}

inflammation which is associated to transplant rejection or interstitial lung disease [20, 58-60].

HHV-6 DNA was found at similar high frequencies of ca. $20 \%$ in both patient collectives. Interpretation of our results, however, is limited since our PCR protocol may have also detected chromosomally integrated viral DNA [61] and cannot differentiate between HHV-6A and HHV-6B. The latter variant is more commonly implicated in human disease [62]. Moreover, HHV-6 was frequently observed in combination with other herpesviruses (Table 2) as also seen by others [62]. Thus, the contribution of HHV-6 to RTI remains unclear.

Other herpesviruses (VZV, HSV-2) were found to be negligible in this study (Table 1) which is in line with the literature $[17,20,54,63]$.

Most of our results were obtained by end-point PCR. The consideration of viral concentration - as it is exemplarily shown here for EBV - may be useful in order to better unravel the contribution of herpesviruses to the development of lung pathology [20]. The observed frequencies of respiratory viruses were comparable to data from the German Laboratory
Network (https://clinical-virology.net/en/charts/chart/ctype/ count/network/resp/section/viruses) and to another study from Germany [64]. Genome equivalents of RSV and HRV were prevalent in children while HRV and IV were frequent in adults. Interestingly, immunocompromised adults tended to have a higher prevalence of RSV (Table 1). This supports previous data on the contribution of RSV to morbidity and mortality in this patient group [65].

There were various examples of single detections, which are probably indicative for infection, but also of co-presence of two or more pathogens (Table 2, Supplementary Fig. 1). Bocaviral DNA, for instance, was frequently found in combination together with further viral genomes as also reported by others [66]. In children of 2 years and younger, however, this parvovirus was detected solely. Previously, isolated BoV infection was shown to be a likely cause of severe acute RTI in children [67]. In a German study, BoV DNA was demonstrated in $10.3 \%$ of nasal swabs obtained from children with respiratory symptoms [68]. This prevalence is largely comparable to our results. Same authors indicated a mean age of 1.8 years 
Table 2 (continued)

\begin{tabular}{|c|c|c|c|c|c|c|c|c|c|c|c|c|c|c|c|c|}
\hline $\begin{array}{l}\text { b) Immunocompromised } \\
\text { patients }\end{array}$ & 交 & خे & نे & य & 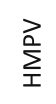 & æ⿱口⿰土口 & $\stackrel{\pi}{\geq}$ & $\stackrel{\infty}{\geq}$ & $\geqq$ & 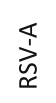 & $\sum_{\nsim}^{\infty}$ & $\gtreqless$ & 豈 & $\begin{array}{l}\varphi^{0} \\
\text { 主 }\end{array}$ & 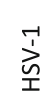 & $\stackrel{\dot{x}}{\dot{\Sigma}}$ \\
\hline & 225 & 225 & 225 & 222 & 225 & 225 & 225 & 225 & 225 & 225 & 225 & 225 & 178 & 71 & 225 & 225 \\
\hline AdV & 3 & 0 & 0 & 0 & 0 & 0 & 0 & 0 & 0 & 0 & 0 & 1 & 0 & 0 & 0 & 0 \\
\hline BoV & & 4 & 0 & 0 & 0 & 1 & 1 & 0 & 0 & 0 & 3 & 0 & 1 & 0 & 0 & 0 \\
\hline $\mathrm{CoV}$ & & & 6 & 0 & 0 & 0 & 0 & 0 & 0 & 0 & 1 & 0 & 1 & 0 & 3 & 0 \\
\hline EV & & & & 2 & 0 & 0 & 0 & 0 & 0 & 0 & 0 & 0 & 1 & 0 & 1 & 0 \\
\hline HMPV & & & & & 4 & 1 & 0 & 0 & 0 & 0 & 0 & 0 & 0 & 0 & 0 & 0 \\
\hline HRV & & & & & & 30 & 1 & 0 & 2 & 3 & 0 & 4 & 6 & 1 & 1 & 0 \\
\hline IV-A & & & & & & & 12 & 0 & 0 & 0 & 1 & 3 & 2 & 2 & 1 & 0 \\
\hline IV-B & & & & & & & & 1 & 0 & 0 & 0 & 0 & 1 & 0 & 0 & 0 \\
\hline PIV & & & & & & & & & 7 & 1 & 0 & 1 & 2 & 1 & 1 & 0 \\
\hline RSV-A & & & & & & & & & & 13 & 0 & 1 & 4 & 0 & 0 & 0 \\
\hline RSV-B & & & & & & & & & & & 7 & 1 & 2 & 0 & 0 & 0 \\
\hline $\mathrm{CMV}$ & & & & & & & & & & & & 44 & 16 & 3 & 11 & 1 \\
\hline EBV & & & & & & & & & & & & & 55 & 6 & 8 & 1 \\
\hline HHV-6 & & & & & & & & & & & & & & 15 & 4 & 0 \\
\hline HSV-1 & & & & & & & & & & & & & & & 32 & 0 \\
\hline M.p. & & & & & & & & & & & & & & & & 1 \\
\hline
\end{tabular}

for BoV detection. In 39.1\%, bocaviral DNA was detected together with other pathogens [68].

Interestingly, analysis of the EV 5'-NTR sequences gave some evidence for the presence of EV-D68 in the airways of three adults and one toddler. EV-D68 infection is associated with the development of acute flaccid myelitis and severe respiratory illness [69].

Parechoviral RNA was found only in a 2-year-old immunocompetent child with IA-V infection. Human parechoviruses can cause mild gastrointestinal and respiratory disease but also sepsis-like illness and meningitis in infants [70]. The general low prevalence of $\mathrm{HPeV}$ in this study is in line with a previous report [64].

The possible etiology of RTI was not clarified in $45.9 \%$ of immunocompromised children (Table 1). Under these conditions, application of broad diagnostic technologies like nextgeneration sequencing could be useful in identification of the underlying pathogen [71]. Moreover, CMV detection rate in samples from the URT of immunocompetent children was surprisingly high (Table 1).

Seasonal effects were evident for several respiratory viruses (Supplementary Table 2). Slight seasonality was also observed for HHV-6 in immunocompetent patients. Interpretation of this finding, however, is unclear. The high prevalence of M.p. in
2011 may be explained by an epidemic observed in Germany [72]. In line with this, the 2009 pandemic caused by A/H1N1pdm09 may account for a further study bias.

DNA of C.p. was generally not detected in our study. This is in line with the low prevalence of $0.2 \%$ reported recently [73], but also with data from the Respiratory Viruses Network (https://clinical-virology.net/en/charts/chart/ctype/count/ network/resp/section/bacteria). It is hypothesized that the prevalence of C.p. was overestimated in previous reports, most likely due to usage of nested-PCR methods or inclusion of serological data. Previously, both C.p. and M.p. were found to be not relevant in critically ill patients with hospitalacquired respiratory tract infections [74].

In summary, with PCR, we found a high prevalence of viral pathogens in the respiratory airways of immunocompetent and immunocompromised patients. In addition, we demonstrated co-presence of several viruses, presumably due to reactivation of herpesviruses.

Acknowledgments The authors would like to thank all patients and their families for study support. Furthermore, the great contribution of attended physicians is kindly acknowledged. The authors thank Fabian Cundano Maltez, Rosemarie Carius, and Martina Müller for their excellent technical service. In addition, we are grateful for the continuous support given by Prof. Andreas Sauerbrei, Prof. Eberhard Straube, Prof. Peter Wutzler, Dr. Heike Hoyer, and Antje Brandstädt. 
Table 2 (continued)

\begin{tabular}{|c|c|c|c|c|c|c|c|c|c|c|c|c|c|c|c|c|c|c|}
\hline $\begin{array}{c}\text { c) Immunocompetent } \\
\text { patients }\end{array}$ & 京 & Dे & उ্ & 己 & $\underset{\text { ¿ }}{\text { ¿ }}$ & $\begin{array}{l}\text { ऐ } \\
\text { 主 }\end{array}$ & $\underset{\dddot{x}}{\gtrless}$ & $\stackrel{\mathbb{1}}{\geq}$ & $\stackrel{\infty}{\geq}$ & $\geq$ & 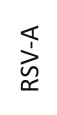 & $\underset{\check{x}}{\stackrel{\infty}{1}}$ & $\gtreqless$ & 总 & $\begin{array}{l}\varphi^{0} \\
\text { 至 }\end{array}$ & $\begin{array}{l}-1 \\
\stackrel{1}{1}\end{array}$ & $\stackrel{\mathrm{J}}{>}$ & $\stackrel{\dot{j}}{\dot{\Sigma}}$ \\
\hline & 266 & 266 & 266 & 264 & 266 & 264 & 266 & 266 & 266 & 266 & 266 & 266 & 266 & 199 & 87 & 266 & 107 & 266 \\
\hline $\mathrm{AdV}$ & 5 & 0 & 0 & 0 & 0 & 0 & 2 & 0 & 0 & 0 & 1 & 1 & 0 & 0 & 1 & 0 & 0 & 0 \\
\hline BoV & & 8 & 2 & 0 & 0 & 0 & 3 & 0 & 0 & 0 & 1 & 0 & 2 & 0 & 1 & 0 & 0 & 0 \\
\hline $\mathrm{CoV}$ & & & 9 & 0 & 0 & 0 & 3 & 1 & 0 & 0 & 2 & 0 & 1 & 0 & 3 & 0 & 0 & 0 \\
\hline EV & & & & 8 & 0 & 0 & 1 & 2 & 0 & 1 & 1 & 1 & 0 & 0 & 0 & 0 & 0 & 0 \\
\hline HMPV & & & & & 7 & 0 & 0 & 0 & 0 & 0 & 0 & 0 & 1 & 0 & 0 & 1 & 0 & 0 \\
\hline $\mathrm{HPeV}$ & & & & & & 1 & 0 & 1 & 0 & 0 & 0 & 0 & 0 & 0 & 0 & 0 & 0 & 0 \\
\hline HRV & & & & & & & 39 & 1 & 0 & 0 & 2 & 1 & 2 & 3 & 2 & 0 & 0 & 2 \\
\hline IV-A & & & & & & & & 37 & 0 & 0 & 1 & 0 & 1 & 3 & 2 & 2 & 0 & 0 \\
\hline IV-B & & & & & & & & & 3 & 0 & 0 & 0 & 0 & 1 & 0 & 0 & 0 & 0 \\
\hline PIV & & & & & & & & & & 5 & 0 & 0 & 0 & 1 & 0 & 0 & 0 & 0 \\
\hline RSV-A & & & & & & & & & & & 25 & 0 & 5 & 0 & 1 & 2 & 0 & 0 \\
\hline RSV-B & & & & & & & & & & & & 10 & 2 & 0 & 2 & 0 & 0 & 0 \\
\hline $\mathrm{CMV}$ & & & & & & & & & & & & & 21 & 3 & 4 & 2 & 0 & 0 \\
\hline EBV & & & & & & & & & & & & & & 29 & 4 & 2 & 0 & 7 \\
\hline HHV-6 & & & & & & & & & & & & & & & 17 & 1 & 0 & 2 \\
\hline HSV-1 & & & & & & & & & & & & & & & & 19 & - & 2 \\
\hline VZV & & & & & & & & & & & & & & & & & 1 & 0 \\
\hline M.p. & & & & & & & & & & & & & & & & & & 17 \\
\hline
\end{tabular}

Authors' contributions AK and RZ conceived the study, helped with interpretation of data, and wrote the manuscript together with MW who performed statistical analyses. MR and CWO tested all respiratory tract samples by PCR and analyzed available patient data in frame of their M.D. theses. Testing of nucleic acids for the presence of EV, HRV, and $\mathrm{HPeV}$ was partially done by FK and SW as part of their bachelor theses. $\mathrm{BG}$ and RE continuously supported the collection and analysis of samples. All authors read and approved the final version of this manuscript.

Funding Open Access funding enabled and organized by Projekt DEAL.

\section{Compliance with ethical standards}

The study was approved by the Ethics committee of the Jena University Hospital (2612-07/09).

Conflict of interest The authors declare that they have no conflict of interest.

Open Access This article is licensed under a Creative Commons Attribution 4.0 International License, which permits use, sharing, adaptation, distribution and reproduction in any medium or format, as long as you give appropriate credit to the original author(s) and the source, provide a link to the Creative Commons licence, and indicate if changes were made. The images or other third party material in this article are included in the article's Creative Commons licence, unless indicated otherwise in a credit line to the material. If material is not included in the article's Creative Commons licence and your intended use is not permitted by statutory regulation or exceeds the permitted use, you will need to obtain permission directly from the copyright holder. To view a copy of this licence, visit http://creativecommons.org/licenses/by/4.0/.

\section{References}

1. Tang JW, Lam TT, Zaraket H, Lipkin WI, Drews SJ, Hatchette TF, Heraud JM, Koopmans MP (2017) Global epidemiology of noninfluenza RNA respiratory viruses: data gaps and a growing need for surveillance. Lancet Infect Dis 17(10):e320-e326. https://doi. org/10.1016/S1473-3099(17)30238-4

2. Grim SA, Reid GE, Clark NM (2017) Update in the treatment of non-influenza respiratory virus infection in solid organ transplant recipients. Expert Opin Pharmacother 18(8):767-779. https://doi. org/10.1080/14656566.2017.1322063

3. Fishman JA (2015) Pulmonary infection in immunocompromised hosts. In: Grippi MA, Elias JA, Fishman JA et al (eds) Fishman's pulmonary diseases and disorders. McGraw-Hill Medical, New York

4. Maeda T, Babazono A, Nishi T, Yasui M, Matsuda S, Fushimi K, Fujimori K (2015) The impact of opportunistic infections on clinical outcome and healthcare resource uses for adult $\mathrm{T}$ cell leukaemia. PLoS One 10(8):e0135042. https://doi.org/10.1371/journal.pone. 0135042 
5. Sandherr M, Hentrich M, von Lilienfeld-Toal M, Massenkeil G, Neumann S, Penack O, Biehl L, Cornely OA (2015) Antiviral prophylaxis in patients with solid tumours and haematological malignancies - update of the guidelines of the infectious diseases working party (AGIHO) of the German Society for Hematology and Medical Oncology (DGHO). Ann Hematol 94(9):1441-1450. https://doi.org/10.1007/s00277-015-2447-3

6. Feldman AG, Sundaram SS, Beaty BL, Kempe A (2017) Hospitalizations for respiratory syncytial virus and vaccinepreventable infections in the first 2 years after pediatric liver transplant. J Pediatr 182(232-238):e231. https://doi.org/10.1016/j. jpeds.2016.12.021

7. Ison MG, Michaels MG (2009) RNA respiratory viral infections in solid organ transplant recipients. Am J Transplant Off J Am Soc Transplant Am Soc Transplant Surg 9(Suppl 4):S166-S172. https:// doi.org/10.1111/j.1600-6143.2009.02908.x

8. Kunisaki KM, Janoff EN (2009) Influenza in immunosuppressed populations: a review of infection frequency, morbidity, mortality, and vaccine responses. Lancet Infect Dis 9(8):493-504. https://doi. org/10.1016/S1473-3099(09)70175-6

9. Weigt SS, Gregson AL, Deng JC, Lynch JP 3rd, Belperio JA (2011) Respiratory viral infections in hematopoietic stem cell and solid organ transplant recipients. Seminars in respiratory and critical care medicine 32(4):471-493. https://doi.org/10.1055/s-00311283286

10. Griffiths C, Drews SJ, Marchant DJ (2017) Respiratory syncytial virus: infection, detection, and new options for prevention and treatment. Clin Microbiol Rev 30(1):277-319. https://doi.org/10.1128/ CMR.00010-16

11. Egli A, Bucher C, Dumoulin A, Stern M, Buser A, Bubendorf L, Gregor M, Servida P, Sommer G, Bremerich J, Gratwohl A, Khanna N, Widmer AF, Battegay M, Tamm M, Hirsch HH, Halter JP (2012) Human metapneumovirus infection after allogeneic hematopoietic stem cell transplantation. Infection 40(6):677684. https://doi.org/10.1007/s15010-012-0279-9

12. Babady NE (2016) Laboratory diagnosis of infections in cancer patients: challenges and opportunities. J Clin Microbiol 54(11): 2635-2646. https://doi.org/10.1128/JCM.00604-16

13. Mayer LM, Kahlert C, Rassouli F, Vernazza P, Albrich WC (2017) Impact of viral multiplex real-time PCR on management of respiratory tract infection: a retrospective cohort study. Pneumonia (Nathan) 9:4. https://doi.org/10.1186/s41479-017-0028-z

14. El Chaer F, Shah DP, Kmeid J, Ariza-Heredia EJ, Hosing CM, Mulanovich VE, Chemaly RF (2017) Burden of human metapneumovirus infections in patients with cancer: risk factors and outcomes. Cancer 123(12):2329-2337. https://doi.org/10. 1002/cncr.30599

15. Fishman JA (2017) Infection in organ transplantation. Am J Transplant Off J Am Soc Transplant Am Soc Transplant Surg 17(4):856-879. https://doi.org/10.1111/ajt.14208

16. Shahani L, Ariza-Heredia EJ, Chemaly RF (2017) Antiviral therapy for respiratory viral infections in immunocompromised patients. Expert Rev Anti-Infect Ther 15(4):401-415. https://doi.org/10. 1080/14787210.2017.1279970

17. Paulsen GC, Danziger-Isakov L (2017) Respiratory viral infections in solid organ and hematopoietic stem cell transplantation. Clin Chest Med 38(4):707-726. https://doi.org/10.1016/j.ccm.2017.07. 012

18. Abad CL, Razonable RR (2017) Treatment of alpha and beta herpesvirus infections in solid organ transplant recipients. Expert Rev Anti-Infect Ther 15(2):93-110. https://doi.org/10.1080/14787210. 2017.1266253

19. Hirsch HH (2010) Transplantationsvirologie. In: Doerr HW, Gerlich WH (eds) Medizinische Virologie, vol 2. Georg-Thieme Verlag, Stuttgart, pp 288-299
20. Reid GE, Lynch JP 3rd, Weigt S, Sayah D, Belperio JA, Grim SA, Clark NM (2016) Herpesvirus respiratory infections in immunocompromised patients: epidemiology, management, and outcomes. Semin Respir Crit Care Med 37(4):603-630. https://doi.org/10. 1055/s-0036-1584793

21. Ernst J, Sauerbrei A, Krumbholz A, Egerer R, Mentzel HJ, Kurzai M, Hafer R, Beck JF, Gruhn B (2012) Multiple viral infections after haploidentical hematopoietic stem cell transplantation in a child with acute lymphoblastic leukemia. Transpl Infect Dis 14(5):E82E88. https://doi.org/10.1111/j.1399-3062.2012.00778.x

22. Almand EA, Moore MD, Jaykus LA (2017) Virus-bacteria interactions: an emerging topic in human infection. Viruses 9(3). https:// doi.org/10.3390/v9030058

23. Bakaletz LO (2017) Viral-bacterial co-infections in the respiratory tract. Curr Opin Microbiol 35:30-35. https://doi.org/10.1016/j.mib. 2016.11.003

24. Martin-Loeches I, van Someren GF, Schultz MJ (2017) Bacterial pneumonia as an influenza complication. Curr Opin Infect Dis 30(2):201-207. https://doi.org/10.1097/QCO. 0000000000000347

25. Panoskaltsis-Mortari A, Griese M, Madtes DK, Belperio JA, Haddad IY, Folz RJ, Cooke KR (2011) An official American Thoracic Society research statement: noninfectious lung injury after hematopoietic stem cell transplantation: idiopathic pneumonia syndrome. Am J Respir Crit Care Med 183(9):1262-1279. https://doi. org/10.1164/rccm.2007-413ST

26. Langelier C, Zinter MS, Kalantar K, Yanik GA, Christenson S, O'Donovan B, White C, Wilson M, Sapru A, Dvorak CC, Miller S, Chiu CY, DeRisi JL (2017) Metagenomic sequencing detects respiratory pathogens in hematopoietic cellular transplant patients. Am J Respir Crit Care Med. https://doi.org/10.1164/rccm.2017061097LE

27. Gorcea CM, Tholouli E, Turner A, Saif M, Davies E, Battersby E, Dignan FL (2017) Effective use of oral ribavirin for respiratory syncytial viral infections in allogeneic haematopoietic stem cell transplant recipients. J Hosp Infect 95(2):214-217. https://doi.org/ 10.1016/j.jhin.2016.11.012

28. Inkster T, Ferguson K, Edwardson A, Gunson R, Soutar R (2017) Consecutive yearly outbreaks of respiratory syncytial virus in a haemato-oncology ward and efficacy of infection control measures. The Journal of hospital infection 96(4):353-359. https://doi.org/10. 1016/j.jhin.2017.05.002

29. Helantera I, Anttila VJ, Loginov R, Lempinen M (2017) Parainfluenza 3 infections early after kidney or simultaneous pancreas-kidney transplantation. Am J Transplant Off J Am Soc Transplant Am Soc Transplant Surg 17(3):809-812. https://doi. org/10.1111/ajt.14146

30. Engelmann I, Dewilde A, Lazrek M, Batteux M, Hamissi A, Yakoub-Agha I, Hober D (2017) In vivo persistence of human rhinoviruses in immunosuppressed patients. PLoS One 12(2): e0170774. https://doi.org/10.1371/journal.pone.0170774

31. Wylie KM (2017) The Virome of the human respiratory tract. Clin Chest Med 38(1):11-19. https://doi.org/10.1016/j.ccm.2016.11. 001

32. Izadyar F, Pau F, Marh J, Slepko N, Wang T, Gonzalez R, Ramos T, Howerton K, Sayre C, Silva F (2008) Generation of multipotent cell lines from a distinct population of male germ line stem cells. Reproduction 135(6):771-784. https://doi.org/10.1530/REP-070479

33. Schittek B, Sauer B, Garbe C (1999) Lack of p73 mutations and late occurrence of $\mathrm{p} 73$ allelic deletions in melanoma tissues and cell lines. Int J Cancer 82(4):583-586

34. Puchhammer-Stockl E, Popow-Kraupp T, Heinz FX, Mandl CW, Kunz C (1990) Establishment of PCR for the early diagnosis of herpes simplex encephalitis. J Med Virol 32(2):77-82 
35. Gressens P, Martin JR (1994) HSV-2 DNA persistence in astrocytes of the trigeminal root entry zone: double labeling by in situ PCR and immunohistochemistry. J Neuropathol Exp Neurol 53(2): $127-135$

36. Puchhammer-Stockl E, Popow-Kraupp T, Heinz FX, Mandl CW, Kunz C (1991) Detection of varicella-zoster virus DNA by polymerase chain reaction in the cerebrospinal fluid of patients suffering from neurological complications associated with chicken pox or herpes zoster. J Clin Microbiol 29(7):1513-1516

37. Puchhammer-Stockl E, Heinz FX, Kundi M, Popow-Kraupp T, Grimm G, Millner MM, Kunz C (1993) Evaluation of the polymerase chain reaction for diagnosis of herpes simplex virus encephalitis. J Clin Microbiol 31(1):146-148

38. Prosch S, Kimel V, Dawydowa I, Kruger DH (1992) Monitoring of patients for cytomegalovirus after organ transplantation by centrifugation culture and PCR. J Med Virol 38(4):246-251

39. Sauerbrei A, Eichhorn U, Schacke M, Wutzler P (1999) Laboratory diagnosis of herpes zoster. J Clin Virol 14(1):31-36

40. Gordon L, McQuaid S, Cosby SL (1996) Detection of herpes simplex virus (types 1 and 2) and human herpesvirus 6 DNA in human brain tissue by polymerase chain reaction. Clin Diagn Virol 6(1): 33-40

41. Gopal MR, Thomson BJ, Fox J, Tedder RS, Honess RW (1990) Detection by PCR of HHV-6 and EBV DNA in blood and oropharynx of healthy adults and HIV-seropositives. Lancet 335(8705): $1598-1599$

42. Krumbholz A, Meerbach A, Zell R, Gruhn B, Henke A, BirchHirschfeld E, Wutzler P (2006) Comparison of a LightCyclerbased real-time PCR for quantitation of Epstein-Barr viral load in different clinical specimens with semiquantitative PCR. J Med Virol 78(5):598-607. https://doi.org/10.1002/jmv.20581

43. Benschop KS, Schinkel J, Minnaar RP, Pajkrt D, Spanjerberg L, Kraakman HC, Berkhout B, Zaaijer HL, Beld MG, Wolthers KC (2006) Human parechovirus infections in Dutch children and the association between serotype and disease severity. Clin Infect Dis 42(2):204-210. https://doi.org/10.1086/498905

44. Baumgarte S, de Souza Luna LK, Grywna K, Panning M, Drexler JF, Karsten C, Huppertz HI, Drosten C (2008) Prevalence, types, and RNA concentrations of human parechoviruses, including a sixth parechovirus type, in stool samples from patients with acute enteritis. J Clin Microbiol 46(1):242-248. https://doi.org/10.1128/ JCM.01468-07

45. Wisdom A, Leitch EC, Gaunt E, Harvala H, Simmonds P (2009) Screening respiratory samples for detection of human rhinoviruses (HRVs) and enteroviruses: comprehensive VP4-VP2 typing reveals high incidence and genetic diversity of HRV species C. J Clin Microbiol 47(12):3958-3967. https://doi.org/10.1128/JCM. 00993-09

46. Tamura K, Stecher G, Peterson D, Filipski A, Kumar S (2013) MEGA6: molecular evolutionary genetics analysis version 6.0. Mol Biol Evol 30(12):2725-2729. https://doi.org/10.1093/ molbev/mst197

47. Moesker FM, van Kampen JJ, van Rossum AM, de Hoog M, Koopmans MP, Osterhaus AD, Fraaij PL (2016) Viruses as sole causative agents of severe acute respiratory tract infections in children. PLoS One 11(3):e0150776. https://doi.org/10.1371/journal. pone. 0150776

48. Sauerbrei A, Schmitt S, Scheper T, Brandstadt A, Saschenbrecker S, Motz M, Soutschek E, Wutzler P (2011) Seroprevalence of herpes simplex virus type 1 and type 2 in Thuringia, Germany, 1999 to 2006. Euro Surveill 16(44)

49. Wutzler P, Farber I, Wagenpfeil S, Bisanz H, Tischer A (2001) Seroprevalence of varicella-zoster virus in the German population. Vaccine 20(1-2):121-124

50. Fourcade G, Germi R, Guerber F, Lupo J, Baccard M, Seigneurin A, Semenova T, Morand P, Epaulard O (2017) Evolution of EBV seroprevalence and primary infection age in a French hospital and a city laboratory network, 2000-2016. PLoS One 12(4):e0175574. https://doi.org/10.1371/journal.pone.0175574

51. Voigt S, Schaffrath Rosario A, Mankertz A (2016) Cytomegalovirus seroprevalence among children and adolescents in Germany: data from the German health interview and examination survey for children and adolescents (KiGGS), 2003-2006. Open Forum Infect Dis 3(1):ofv193. https://doi.org/10.1093/ofid/ ofv193

52. Braun DK, Dominguez G, Pellett PE (1997) Human herpesvirus 6. Clin Microbiol Rev 10(3):521-567

53. Jenkins FJ, Rowe DT, Rinaldo CR Jr (2003) Herpesvirus infections in organ transplant recipients. Clin Diagn Lab Immunol 10(1):1-7

54. Costa C, Sidoti F, Saldan A, Sinesi F, Balloco C, Simeone S, Lorusso M, Mantovani S, Merlino C, Solidoro P, Cavallo R (2012) Clinical impact of HSV-1 detection in the lower respiratory tract from hospitalized adult patients. Clin Microbiol Infect 18(8): E305-E307. https://doi.org/10.1111/j.1469-0691.2012.03882.x

55. Costa C, Elia M, Astegiano S, Sidoti F, Terlizzi ME, Solidoro P, Botto S, Libertucci D, Bergallo M, Cavallo R (2008) Quantitative detection of Epstein-Barr virus in bronchoalveolar lavage from transplant and nontransplant patients. Transplantation 86(10): 1389-1394. https://doi.org/10.1097/TP.0b013e3181890415

56. Friedrichs I, Bingold T, Keppler OT, Pullmann B, Reinheimer C, Berger A (2013) Detection of herpesvirus EBV DNA in the lower respiratory tract of ICU patients: a marker of infection of the lower respiratory tract? Med Microbiol Immunol 202(6):431-436. https:// doi.org/10.1007/s00430-013-0306-1

57. Liu QF, Fan ZP, Luo XD, Sun J, Zhang Y, Ding YQ (2010) Epstein-Barr virus-associated pneumonia in patients with posttransplant lymphoproliferative disease after hematopoietic stem cell transplantation. Transpl Infect Dis 12(4):284-291. https://doi.org/ 10.1111/j.1399-3062.2010.00502.x

58. Azadeh N, Limper AH, Carmona EM, Ryu JH (2017) The role of infection in interstitial lung diseases: a review. Chest 152(4):842852. https://doi.org/10.1016/j.chest.2017.03.033

59. Krumbholz A, Sandhaus T, Gohlert A, Heim A, Zell R, Egerer R, Breuer M, Straube E, Wutzler P, Sauerbrei A (2010) Epstein-Barr virus-associated pneumonia and bronchiolitis obliterans syndrome in a lung transplant recipient. Med Microbiol Immunol 199(4):317322. https://doi.org/10.1007/s00430-010-0165-y

60. Engelmann I, Welte T, Fuhner T, Simon AR, Mattner F, Hoy L, Schulz TF, Gottlieb J (2009) Detection of Epstein-Barr virus DNA in peripheral blood is associated with the development of bronchiolitis obliterans syndrome after lung transplantation. J Clin Virol 45(1):47-53. https://doi.org/10.1016/j.jcv.2009.02.005

61. Pellett PE, Ablashi DV, Ambros PF, Agut H, Caserta MT, Descamps V, Flamand L, Gautheret-Dejean A, Hall CB, Kamble RT, Kuehl U, Lassner D, Lautenschlager I, Loomis KS, Luppi M, Lusso P, Medveczky PG, Montoya JG, Mori Y, Ogata M, Pritchett JC, Rogez S, Seto E, Ward KN, Yoshikawa T, Razonable RR (2012) Chromosomally integrated human herpesvirus 6: questions and answers. Rev Med Virol 22(3):144-155. https://doi.org/10. 1002/rmv.715

62. Lautenschlager I, Razonable RR (2012) Human herpesvirus-6 infections in kidney, liver, lung, and heart transplantation: review. Transpl Int 25(5):493-502. https://doi.org/10.1111/j.1432-2277. 2012.01443.x

63. Mohsen AH, McKendrick M (2003) Varicella pneumonia in adults. Eur Respir J 21(5):886-891

64. Bierbaum S, Forster J, Berner R, Rucker G, Rohde G, NeumannHaefelin D, Panning M, group Cs (2014) Detection of respiratory viruses using a multiplex real-time PCR assay in Germany, 2009/10. Arch Virol 159(4):669-676. https://doi.org/10.1007/ s00705-013-1876-3 
65. Volling C, Hassan K, Mazzulli T, Green K, Al-Den A, Hunter P, Mangat R, Ng J, McGeer A (2014) Respiratory syncytial virus infection-associated hospitalization in adults: a retrospective cohort study. BMC Infect Dis 14:665. https://doi.org/10.1186/s12879014-0665-2

66. Broccolo F, Falcone V, Esposito S, Toniolo A (2015) Human bocaviruses: possible etiologic role in respiratory infection. J Clin Virol 72:75-81. https://doi.org/10.1016/j.jcv.2015.09.008

67. Moesker FM, van Kampen JJ, van der Eijk AA, van Rossum AM, de Hoog M, Schutten M, Smits SL, Bodewes R, Osterhaus AD, Fraaij PL (2015) Human bocavirus infection as a cause of severe acute respiratory tract infection in children. Clin Microbiol Infect 21(10):964 e961-964 e968. https://doi.org/10.1016/j.cmi.2015.06. 014

68. Weissbrich B, Neske F, Schubert J, Tollmann F, Blath K, Blessing K, Kreth HW (2006) Frequent detection of bocavirus DNA in German children with respiratory tract infections. BMC Infect Dis 6:109. https://doi.org/10.1186/1471-2334-6-109

69. Sun J, Hu XY, Yu XF (2019) Current understanding of human enterovirus D68. Viruses 11(6). https://doi.org/10.3390/v11060490

70. de Crom SC, Rossen JW, van Furth AM, Obihara CC (2016) Enterovirus and parechovirus infection in children: a brief overview. Eur J Pediatr 175(8):1023-1029. https://doi.org/10.1007/ s00431-016-2725-7
71. Kustin T, Ling G, Sharabi S, Ram D, Friedman N, Zuckerman N, Bucris ED, Glatman-Freedman A, Stern A, Mandelboim M (2019) A method to identify respiratory virus infections in clinical samples using next-generation sequencing. Sci Rep 9(1):2606. https://doi. org/10.1038/s41598-018-37483-w

72. Dumke R, Schnee C, Pletz MW, Rupp J, Jacobs E, Sachse K, Rohde G, Capnetz Study G (2015) Mycoplasma pneumoniae and Chlamydia spp. infection in community-acquired pneumonia, Germany, 2011-2012. Emerg Infect Dis 21(3):426-434. https:// doi.org/10.3201/eid2103.140927

73. Padalko E, Boel A, Lagrou K, Reynders M, China B, Vernelen K, Expert Committee on Infectious S (2013) Low yield by molecular detection of Chlamydophila pneumoniae in respiratory samples in Belgium questioning its etiological role in respiratory tract infections. Acta Clin Belg 68(3):166-168. https://doi.org/10.2143/ACB. 3241

74. Hagel S, Schmitt S, Kesselmeier M, Baier M, Welte T, Ewig S, Pletz MW (2019) M. pneumoniae and C. pneumoniae are no relevant pathogens in critically ill patients with hospital-acquired respiratory tract infections. Infection 47(3):471-474. https://doi.org/10. 1007/s15010-019-01273-x

Publisher's note Springer Nature remains neutral with regard to jurisdictional claims in published maps and institutional affiliations. 